\title{
Weed management in maize using hoeing and intercropping with Mimosa caesalpiniifolia
}

\author{
Homero N. Sampaio ${ }^{1}$, Paulo S. L. e Silva² ${ }^{2}$ Alex L. Monteiro², Leonardo B. Tavella ${ }^{2}$ \& Vianney R. de Oliveira ${ }^{2}$ \\ ${ }^{1}$ Instituto Federal de Educação, Ciência e Tecnologia. Crato, CE. E-mail: honosa2007@uol.com.br \\ ${ }^{2}$ Departamento de Ciências Vegetais/Universidade Federal Rural do Semi-Árido. Mossoró, RN. E-mail: paulosergio@ufersa.edu.br (Corresponding \\ author); alex_monteiro02@hotmail.com; leo_tavella@hotmail.com; vianney.reinaldo@hotmail.com
}

\section{Key words:}

Zea mays

integrated weed management yield components

\begin{abstract}
A B S T R A C T
The objective of this study was to evaluate the weed management in maize using hoeing and intercropping with Mimosa caesalpiniifolia ('sabiá). A randomized block design that consisted of split plots and five replicates was used. The hybrids AG1051 and BR205 (plots) received the following treatments: $A=$ hoeing [20 and 40 days after sowing the maize (DASM) and without intercropping]; B = hoeing 20 DASM followed by the planting of 'sabiá; $\mathrm{C}=$ planting of 'sabiá at the time the maize was sown followed by hoeing 40 DASM; D = planting of 'sabiá at the time the maize was sown; and $\mathrm{E}=$ no hoeing and without intercropping. Lesser weed growth in the plots of two hybrids was observed with the treatments that involved hoeing. The highest yields for maize were obtained with two hoeings. The combinations of hoeing and intercropping provided higher grain yield compared to only intercropping with sabiá. Grain yield with hoeing 20 DASM and intercropping with sabiá was higher compared to intercropping with sabiá and hoeing 40 DASM.
\end{abstract}

\section{Palavras-chave: \\ Zea mays \\ manejo integrado de plantas daninhas componentes da produção}

\section{Manejo de plantas daninhas em milho usando capinas e consorciação com Mimosa caesalpiniifolia}

\begin{abstract}
R E S U M O
O objetivo do trabalho foi avaliar o manejo de plantas daninhas no milho, usando-se capinas e consorciação com Mimosa caesalpiniifolia. Utilizou-se o delineamento de blocos ao acaso com parcelas subdivididas e cinco repetições. Os híbridos AG1051 e BR205 (parcelas) receberam os seguintes tratamentos: $\mathrm{A}=$ duas capinas [aos 20 e 40 dias após a semeadura do milho (DASM)] e sem consorciação; $\mathrm{B}=$ capina aos $20 \mathrm{DASM}+$ semeadura de sabiá após a capina; $\mathrm{C}=$ semeadura da sabiá por ocasião da semeadura do milho + capina aos 40 DASM; D = semeadura da sabiá por ocasião da semeadura do milho; $\mathrm{E}=$ sem capinas e sem consorciação. O menor crescimento das plantas daninhas ocorreu nos dois híbridos, com os tratamentos que envolveram capinas. Os maiores rendimentos do milho foram obtidos com duas capinas. As combinações de capinas com a consorciação proporcionaram maior rendimento de grãos em comparação com a consorciação com a sabiá isoladamente. O rendimento de grãos com a capina aos 20 dias após a semeadura do milho (DASM) + consorciação com a sabiá, foi maior do que a consorciação com a sabiá + capina aos 40 DASM.
\end{abstract}




\section{INTRODUCTION}

Integrated weed management (IWM) is a process that combines both direct and indirect strategies for the control of weeds. Direct control strategies include biological, chemical, cultural, and/or physical measures for the control of weeds. Measures of indirect control involve agronomic practices, which may include the choice of cultivar, crop rotation, sowing period, and nutrient management, among other factors, and are designed to promote the competitive ability of crops (Sanyal et al., 2008; Ronald et al., 2011). The importance of IWM was recognized nearly 80 years ago but currently received increasing attention due to the rapid development of weed biotypes that are resistant to herbicides and to the growing public pressure against the use of pesticides (Harker \& O’Donovan, 2013).

Several studies using either intercropped maize or a maize monoculture have demonstrated that the use of a cover crop can improve the efficiency of IWM. The use of herbicides combined with hoeing and a leguminous cover crop for the intercropping of maize and cassava have been found to result in a greater economic return compared to the individual use of an herbicide or a cover crop or the combinations of these two strategies (Olorunmaiye, 2011). The comparison of the intercropping of cassava and maize revealed that the plots that were either hoed or received herbicides in combination with cover crops provided greater economic benefits for cassava than for maize (Chikoye et al., 2002). Ekpo et al. (2010) found that the combination of an herbicide and the use of melon as the intercrop satisfactorily controlled weeds and resulted in a lowest reduction in maize yield compared to that obtained with two hoeings. In IWM, the selection of the species to be intercropped with maize and the choice of other methods to be used for weed control are important (Yeganehpoor et al., 2013).

For the control of weeds, Oliveira et al. (2011) attempted to intercrop maize with gliricidia [Gliricidia sepium (Jacqquin) Steudel], a leguminous arboreal plant. These researchers found that the intercropped plots provided a higher yield compared to the non-hoed plots but a lower yield compared to the plots that were hoed twice. Thus, to determine the advantages in terms of weed control in maize, the combination of one hoeing (two hoeing are commonly performed in the cultivation of maize) with the planting of gliricidia or other leguminous arboreal plants was performed. In northeastern Brazil, it is important to substitute gliricidia by a similar leguminous plant native to this region, such as sabiá (Mimosa caesalpiniifolia Benth.).

The aim of this study was to evaluate the weed management in maize using hoeing and intercropping with Mimosa caesalpiniifolia.

\section{MAterial AND Methods}

The experiment was carried out from October 2012 to February 2013 at the Rafael Fernandes Experimental Farm (latitude $5^{\circ} 03^{\prime} 49^{\prime \prime} \mathrm{S}$, longitude $37^{\circ} 23^{\prime} 49^{\prime \prime} \mathrm{W}$, at an altitude of $80 \mathrm{~m}$ ). According to the Köppen classification, the climate in the region is the BSwh' type, i.e., dry and very hot, with a rainy season from summer to autumn, an average annual temperature of $27.4{ }^{\circ} \mathrm{C}$, very irregular annual rainfall with an average of 673.9 $\mathrm{mm}$, and a relative humidity of $68.9 \%$. Sunlight increases from
March to October, with an average of $241.7 \mathrm{~h}$. The maximum relative humidity reaches $78 \%$ in April with a minimum of $60 \%$ in September.

The soil in the experimental area is classified as a Red-Yellow Argisol (PVA) (EMBRAPA, 2006). The results of the analysis of a soil sample from the experimental area showed a $\mathrm{pH}$ of 6.46 . The levels of phosphorus, potassium and sodium were 6.4, 85.3 and $66.3 \mathrm{mg} \mathrm{dm}^{-3}$, respectively; for calcium, magnesium, aluminum, hydrogen, the sum of bases, exchangeable bases and cation exchange capacity, the values were 1.69, 1.00, 0.00, 0.74, $3.20,3.20$ and $3.94 \mathrm{cmol} \mathrm{dm}_{\mathrm{c}} \mathrm{dm}^{-3}$, respectively. The base saturation and the percentage of exchangeable sodium were 81 and $7 \%$, respectively. The soil analysis was conducted according to the recommendations of Silva (2009).

The soil in the area was prepared with two harrowings and fertilized with $120 \mathrm{~kg} \mathrm{~N}, 60 \mathrm{~kg} \mathrm{P}_{2} \mathrm{O}_{5}$ and $30 \mathrm{~kg} \mathrm{~K}_{2} \mathrm{O}$ per hectare. Ammonium sulfate, single superphosphate and potassium chloride were used as sources of N, P and K, respectively. The phosphorus and potassium were applied together with one-third of the nitrogen dosage in furrows located beside and below the maize seeds at the time of sowing. The remaining $\mathrm{N}$ was applied as topdressing in two equal parts at 25 and 45 days after sowing and hoeing were conducted.

The experimental design was a randomized block design with split plots and five replications. In the plots, the hybrids AG1051 and BR205 were grown. In the subplots, the following methods of weed control were applied: a) hoeing [ 20 and 40 days after sowing the maize (DASM)] and without intercropping; $b$ ) hoeing at 20 DASM followed by the planting of sabiá (30 viable seeds $\left.\mathrm{m}^{-2}\right) ; \mathrm{c}$ ) sowing of sabia ( 30 viable seeds $\mathrm{m}^{-2}$ ) at the time of sowing the maize, followed by hoeing at 40 DASM; d) sowing of sabiá (30 viable seeds $\mathrm{m}^{-2}$ ) when sowing the maize; and e) no hoeing and without intercropping. When intercropping, the sabia seeds were broadcast and incorporated into the soil with the aid of a rake. The same employee was always assigned to hoe each block.

A subplot consisted of five rows, and each row was $6.0 \mathrm{~m}$ long. The experimental area was defined as the area occupied by the three central rows, from which the plants from the last hole at each end of the row were discarded when harvested. Of the three central rows, one was used to assess grain yield.

The maize was sown with four seeds per hole, at a spacing of $1.0 \mathrm{~m}$ between rows and $0.4 \mathrm{~m}$ between holes. Thinning was conducted 20 days after sowing, leaving two plants per hole.

The experiment was irrigated by sprinkler based on the climatic characteristics of the region and the needs of the crop. The depth of water required daily by the maize $(5.6 \mathrm{~mm})$ was calculated based on an effective depth of $0.40 \mathrm{~m}$ for the root system using an irrigation interval of 2 days. Phytosanitary management was employed for the fall armyworm (Spodoptera frugiperda Smith) by employing two spray applications of a product registered for the crop at 25 and 45 days after sowing. One spray application of a registered product was used to control the corn leafhopper, Dalbulus maidis (DeLong \& Wolcott), at 50 days after sowing.

Weeds were collected 20, 40 and 110 days after sowing (DAS). Forty DAS, weeds were obtained from the sub-plots that received the treatments "two hoeings" and "intercropping with sabiá at sowing until 40 days after sowing." One hundred 
and five DAS, weeds were collected from all of the sub-plots, particularly from an area of $1.00 \mathrm{~m} \times 0.8 \mathrm{~m}$ between two of the three central rows of the sub-plot. The plants were cut level to the ground, identified, and weighed. The identification of the species of weeds from each plot enabled the calculation of the rate of occurrence (number of experimental units in which a determined species occurred/total number of experimental units). To estimate the dry matter weight, a homogeneous sample of the harvested material, with a weight of approximately $200 \mathrm{~g}$, was placed into a forced-air circulation oven at a temperature of $75^{\circ} \mathrm{C}$ until it reached a constant mass.

The sabiá was evaluated 40 (time of sowing to the time of the second hoeing), 90 (time of first hoeing to the time of the final evaluation), and 110 (implementation of the experiment to the time of the final evaluation) days after sowing in terms of the number of plants per $\mathrm{m}^{2}$, the plant height, the stem diameter, and the fresh and dry weights of the shoots. After quantification, the plants were weighed and measured to determine the height of the plant. The stem diameter was determined using a caliper, and the shoot dry mass of the sabiá plants was determined as previously described for the weeds.

Prior to variance analysis, it was determined whether the data were in line with those presuppositions required for performing the analysis (Dias \& Barros, 2009). Variance analysis were conducted using the SAEG software, developed by the Federal University of Viçosa (Ribeiro Júnior, 2001). The averages were compared using the Tukey test at 0.05 probability.

\section{Results AND Discussion}

The results showed that the length of time of coexistence (T) had an effect on the stem diameter of the sabia plants intercropped with maize; however, neither the cultivars $(C)$ nor the $\mathrm{T} \times \mathrm{C}$ interaction exhibited an effect on the stem diameter $\left(\mathrm{CV}_{\text {plots }}=15.1 \% ; \mathrm{CV}_{\text {subplots }}=12.8 \%\right)$. The plants that coexisted with maize for 40 days after sowing (DAS) had a mean stem diameter of $1.7 \mathrm{~mm}$, which was smaller than the diameter of the plants that co-existed for 90 DAS $(2.4 \mathrm{~mm})$ and the stem diameter of the plants that coexisted for $110 \mathrm{DAS}(2.8 \mathrm{~mm})$. Thus, even when subjected to competition from maize and weeds, the sabiá plants grew in terms of their stem diameter.

In addition, the length of time of coexistence of the plants intercropped with maize $(\mathrm{T})$ and the interaction $\mathrm{T} \times$ cultivars affected the number of plants $\mathrm{m}^{-2}$, plant height, and fresh and dry weights of the shoots of the sabiá plants. The number of plants $\mathrm{m}^{-2}$ was reduced over time in both cultivars but was more markedly reduced in the AG1051 cultivar, resulting in a $\mathrm{T} \times$ cultivar interaction (Table 1 ). The plant height of the sabiá increased over time when intercropped with the two maize cultivars but exhibited a sharper increase when intercropped with the BR205 cultivar, resulting in a $\mathrm{T} \times$ cultivar interaction (Table 1). However, the fresh and dry weights of the sabia shoots did not change as a function of time when intercropped with the AG1051 cultivar but increased with the BR205 cultivar (Table 1). The data on the plant height and fresh and dry weights of the sabiá suggest that this leguminous plant suffers from greater competition from the maize cultivar AG1051 compared with the other cultivar (Table 1). Similar results were also observed in other studies (Oliveira et al., 2011) in which gliricidia plants
Table 1. Mean number and fresh and dry weights of the shoots of sabiá plants intercropped with maize hybrids for three different time periods

\begin{tabular}{cccc}
\hline & \multicolumn{3}{c}{ Number of plants m $^{-2}$ (original data) } \\
\cline { 2 - 3 } Hybrid & \multicolumn{3}{c}{ Time of coexistence with the maize plants } \\
(days after sowing)
\end{tabular}

${ }^{1}$ Means followed by the same uppercase letter in the same column and the same lowercase letter in the same row do not differ at 0.05 probability by Tukey's test

were intercropped with maize. That is, these authors also found that the leguminous plant suffered more competition from some maize cultivars.

The maize plants competed with the sabia plants for water, light, nutrients, and space. Based on these factors, the competitive ability of the maize plants in relation to other plants (sabiá or weeds in the present study) may be correlated with the morphological and physiological characteristics of the shoots and root system. This ability may be due to the suppressive ability (SA) and crop tolerance (CT). Considering only the shoots of the maize plants, Zystro et al. (2012) reported that the SA may depend on the period of maturity, plant height, leaf angle, and leaf production, whereas the period of maturity and plant height can affect the CT. These researchers concluded that the plant height is the most predictive characteristic of the SA and CT.

Twenty-two species of weeds were found in the experimental area after the three sampling periods (Table 2). Several results shown in Table 2 should be highlighted. First, some species were not observed in the three samples. In the first sample, $36 \%$ of the 22 species were not observed in the experimental units. In the second and third samples, 9 and 14\%, respectively, of the 22 species were not observed in the experimental plots. In the first sample, the most common species (rate of occurrence greater than 50\%) were Cenchrus equinatus, Ipomoea sp., 
Table 2. Rate of occurrence of the weed species found in the experimental areas of maize grown as a monoculture or intercropped with sabiá at three different time periods

\begin{tabular}{|c|c|c|c|c|c|}
\hline \multirow{3}{*}{ Botanical name } & \multirow{3}{*}{ Local common name } & \multirow{3}{*}{ Family } & \multicolumn{3}{|c|}{ Sampling time (days after sowing) } \\
\hline & & & 20 & 40 & 110 \\
\hline & & & \multicolumn{3}{|c|}{ Rate of occurrence (\%) } \\
\hline Adenocalymma sp. & Cipó-cambará & Bignoniaceae & 35 & 75 & 66 \\
\hline Alternanthera tenella colla & Apaga fogo & Amaranthaceae & 60 & 20 & 30 \\
\hline Amaranthus viridis $\mathrm{L}$. & Caruru & Amaranthaceae & 5 & 15 & 4 \\
\hline Axonopus purpusii (Mez) Chase & Capim mimoso & Poaceae & 0 & 15 & 2 \\
\hline Cenchrus echinatus $\mathrm{L}$. & Capim carrapicho & Poaceae & 90 & 70 & 66 \\
\hline Chamaesyce hyssopifolia (L) Small & Erva Santa Luzia & Euphorbiaceae & 10 & 0 & 4 \\
\hline Combretum leptostachyum Mart. & Mufungo & Combretaceae & 60 & 0 & 0 \\
\hline Corchorus hirtus L. & Vassoura & Malvaceae & 0 & 15 & 0 \\
\hline Cucumis anguria $\mathrm{L}$. & Maxixe & Cucurbitaceae & 20 & 5 & 12 \\
\hline Dactyloctenium aegyptium $\mathrm{L}$. & Capim pé de galinha & Poaceae & 0 & 10 & 8 \\
\hline Ipomoea sp. & Jitirana corda-de-viola & Convolvulaceae & 90 & 25 & 78 \\
\hline Jacquemontia sp. & Jitirana & Convolvulaceae & 85 & 70 & 4 \\
\hline Mimosa candollei R. Grether & Malicia & Fabaceae & 15 & 30 & 28 \\
\hline Panicum maximum Jacq. & Capim colonião & Poaceae & 0 & 20 & 0 \\
\hline Paspalum griseum Hack. & Capim milha & Poaceae & 0 & 40 & 64 \\
\hline Phyllanthus niruri L. & Quebra pedra & Phyllantaceae & 15 & 5 & 4 \\
\hline Rumex acetosella L. & Lingua de vaca & Polygonaceae & 0 & 15 & 10 \\
\hline Senna obtusifolia L. & Mata pasto & Fabaceae & 15 & 5 & 8 \\
\hline Sida cordifolia L. & Malva branca & Malvaceae & 0 & 45 & 10 \\
\hline Solanum agrarium Sendtn. & Melancia de praia & Solanaceae & 50 & 60 & 42 \\
\hline Spigelia sp. & Pimenta dágua & Loganiaceae & 0 & 15 & 6 \\
\hline Turnera ulmifolia L. & Xanana & Turneraceae & 65 & 20 & 4 \\
\hline
\end{tabular}

Jacquemontia sp., Turnera ulmifolia, Alternanthera tenella and Combretum leptostachyum. In the second sample, the most frequently occurring species were Adenocalymma sp., C. equinatus, Jacquemontia sp., and Solanum agrarium, and the most commonly found species in the third sample were Ipomoea sp., Adenocalymma sp., C. equinatus, and Paspalum griseum.

Second, few species were found to be predominant (Table 2 ). The predominance of a few species is consistent with the hypothesis introduced by Buhler (1999). According to this hypothesis, the weed population in a given area is dependent on several factors, and although the population consists of several species, few of these species are predominant, corresponding to 70 to $90 \%$ of the total number of species (Buhler, 1999).

The third result that should be highlighted from the data shown in Table 2 is that some species that were not found or species that were found at lower rates in the first sample were observed in later samples and vice versa. However, some species demonstrated relatively high rates of occurrence in all samples (i.e., C. equinatus), and other species exhibited relatively low rates in all of the samples (i.e., Amaranthus viridis). Many variables are involved in the results presented in Table 2, including the non-random distribution of the species in the field, difficulties associated with sampling, and differences in germination, cycle, competitive ability, and resistance of the weed species to the control methods used (Borgy et al., 2012).

The evaluation performed 40 days after sowing the maize (DAS) revealed that the hybrids and the two control methods, including hoeing, had an effect on the fresh matter of the weed shoots. On average, hybrid AG1051 demonstrated the best control of weeds when hoeing was performed 20 DAS and exhibited better weed control compared to intercropping with sabiá during the 40 -DAS period (Table 3). Moreover, the interaction between the two groups of treatments had an effect on the shoot dry matter of the weeds. When hoeing was performed, there was no difference between the hybrids in terms of the shoot dry matter of the weeds. However, when intercropped with sabiá, hybrid AG1051 controlled the weeds better than the other hybrid. This difference resulted in an interaction between the two treatment groups. Thus, hybrid AG105 showed a greater competitive ability against the sabiá (Table 2) and against weeds. For both hybrids, hoeing 20 DAS resulted in better weed control compared to intercropping with sabiá during the 40-DAS period (Table 3).

Table 3. Mean fresh and dry matters of the weed shoots in the experimental plots of maize hybrids evaluated 40 days after sowing (DAS) ${ }^{1}$

\begin{tabular}{|c|c|c|c|c|c|c|}
\hline \multirow{3}{*}{ Hybrids } & \multicolumn{2}{|c|}{ Treatments (DMS = 179.2) } & \multirow[b]{2}{*}{ Mean } & \multicolumn{2}{|c|}{ Treatments (DMS $=34.8$ ) } & \multirow[b]{2}{*}{ Mean } \\
\hline & $\begin{array}{c}\text { Hoeing } 20 \text { and } 40 \\
\text { DAS }\end{array}$ & $\begin{array}{l}\text { Intercropping with } \\
\text { sabiá at the time } \\
\text { of sowing and } \\
\text { hoeing } 40 \text { DAS }\end{array}$ & & $\begin{array}{c}\text { Hoeing } 20 \text { and } 40 \\
\text { DAS }\end{array}$ & $\begin{array}{l}\text { Intercropping with } \\
\text { sabiá at the time } \\
\text { of sowing and } \\
\text { hoeing } 40 \text { DAS }\end{array}$ & \\
\hline & \multicolumn{3}{|c|}{ Fresh matter $\left(\mathrm{kg} \mathrm{ha}^{-1}\right)$} & \multicolumn{3}{|c|}{ Dry matter $\left(\mathrm{kg} \mathrm{ha}^{-1}\right)$} \\
\hline AG 1051 & 258 & 3317 & $1787 \mathrm{~B}$ & $59 \mathrm{Ab}$ & $414 \mathrm{Ba}$ & 237 \\
\hline BR 205 & 255 & 3544 & $1900 \mathrm{~A}$ & $42 \mathrm{Ab}$ & $557 \mathrm{Aa}$ & 300 \\
\hline Mean & $257 b$ & $3431 \mathrm{a}$ & 1844 & 51 & 486 & 269 \\
\hline DMS for hybrids & & 109.7 & & & 49.2 & \\
\hline $\mathrm{CV}_{\text {plot }}(\%)$ & & 4.7 & & & 14.5 & \\
\hline $\mathrm{CV}_{\text {Subplot }}(\%)$ & & 9.4 & & & 12.5 & \\
\hline
\end{tabular}

${ }^{1}$ Means followed by the same uppercase letter in the same column and the same lowercase letter in the same row do not differ at 0.05 probability by Tukey's test 
The evaluation performed 110 days after sowing the maize (DASM) revealed that the interaction between the hybrids and the methods of weed control exerted an effect on the fresh and dry matters of the weed shoots. For hybrid AG1051, two hoeings and the combination of one hoeing (20 or 40 days after sowing) and intercropping with sabiá resulted in the least growth of weeds in terms of the fresh and dry matters of the shoots (Table 4). For this hybrid, the greatest growth of weeds resulted from the intercropping with sabiá. The lack of hoeing resulted in an intermediate growth of the weeds for the other two treatment groups. For hybrid BR205, the use of two hoeings resulted in the least growth, and a lack of hoeing and intercropping with sabia at sowing resulted in the most growth in terms of the fresh matter of the weed shoots. The remaining treatments resulted in an intermediate growth of the weeds. The analysis of the dry matter of the weed shoots in the sub-plots of hybrid BR205 revealed that two hoeings and the combination of one hoeing and intercropping with sabiá resulted in the least weed growth, whereas a lack of hoeing resulted in the most growth. Intercropping with sabiá from the beginning of the maize cycle resulted in an intermediate growth of weeds (Table 4).

The data shown in Table 4 highlight two observations. First, as observed with hybrid BR205, sabiá controls weeds in relation to a lack of hoeing, although this effect is not as efficient as two hoeings because hoeing eliminates most of the weeds. However, the competition between sabiá and weeds is a slow and complex process that may reduce weed growth but rarely results in their elimination. This fact may explain the superiority of hoeing compared to intercropping with sabiá (Table 4). Second, the competition of sabiá with weeds is dependent on the maize cultivar (Table 4). This finding may help explain why it is not always possible to confirm the efficiency of intercropping in weed control. The cultivars of the crop and the species used for intercropping are both important in weed control. This hypothesis was confirmed by the finding that the intercropping of hybrid AG1051 with sabia throughout the maize cycle resulted in the worst weed control. This result may be due to the negative effect of this hybrid on some of the characteristics of sabiá plants (Table 1), which resulted in less competition between the sabiá plants and the weeds. However, this problem is more complex because the hybrid itself competes with weeds.

The hybrids $(\mathrm{H})$ and methods of weed control $(\mathrm{C})$ affected the number of mature ears per hectare and the 100-grain weight, but the $\mathrm{H} \times \mathrm{C}$ interaction had no effect on these traits. With respect to these two characteristics, two hoeings produced the best result, and the absence of hoeing and intercropping with sabia provided the worst results (Table 5). In addition, the combination of one hoeing and intercropping with sabiá yielded intermediate results in these two traits (Table 5). Interestingly, intercropping with sabiá resulted in a higher 100-grain weight average compared to lack of hoeing, which suggests a beneficial effect of intercropping (Table 5). Furthermore, hybrid BR205 provided better results in terms of the number of ears per hectare but demonstrated worse results for the 100-grain weight (Table 5).

The hybrids $(\mathrm{H})$, methods of weed control $(\mathrm{C})$, and the $\mathrm{H}$ $\times \mathrm{C}$ interaction had effects on the number of grains per ear and the grain yield. For hybrid AG1051, the greatest number of grains per ear was obtained with two hoeings, whereas for the other hybrid, hoeing 20 days after sowing the maize and

Table 4. Mean fresh and dry matters of weed shoots in experimental plots of maize hybrids evaluated 110 days after sowing ${ }^{1}$

\begin{tabular}{|c|c|c|c|c|}
\hline \multirow{4}{*}{ Method of weed control } & \multicolumn{2}{|c|}{ Fresh matter } & \multicolumn{2}{|c|}{ Dry matter } \\
\hline & \multicolumn{4}{|c|}{$\left(\mathrm{kg} \mathrm{ha}^{-1}\right)$} \\
\hline & \multicolumn{4}{|c|}{ Hybrid } \\
\hline & AG1051 & BR205 & AG1051 & BR205 \\
\hline No hoeing & $1998 \mathrm{Bb}$ & $2719 \mathrm{Aa}$ & $450 \mathrm{Bb}$ & $513 \mathrm{Aa}$ \\
\hline Hoeing 20 and 40 days after sowing the maize (DASM) & $1372 \mathrm{Cb}$ & $1743 \mathrm{Da}$ & $242 \mathrm{Ca}$ & $265 \mathrm{Ca}$ \\
\hline Intercropping with sabia at the time of sowing the maize & $3662 \mathrm{Aa}$ & $2446 \mathrm{ABb}$ & $644 \mathrm{Aa}$ & $385 \mathrm{Bb}$ \\
\hline Hoeing 20 DASM and intercropping with sabiá after hoeing & $1685 \mathrm{Cb}$ & $2171 \mathrm{BCa}$ & $313 \mathrm{Ca}$ & $319 \mathrm{Ca}$ \\
\hline Intercropping with sabiá at the time of sowing the maize and hoeing 40 DASM & $1509 \mathrm{Cb}$ & $1940 \mathrm{CDa}$ & $270 \mathrm{Ca}$ & $296 \mathrm{Ca}$ \\
\hline DMS for hybrids & \multicolumn{2}{|c|}{190.9} & \multicolumn{2}{|c|}{56.7} \\
\hline DMS for method of weed control & \multicolumn{2}{|c|}{265.5} & \multicolumn{2}{|c|}{50.4} \\
\hline $\mathrm{CV}_{\text {plot }}(\%)$ & \multicolumn{2}{|c|}{11.4} & \multicolumn{2}{|c|}{19.5} \\
\hline $\mathrm{CV}_{\text {subplot }}(\%)$ & \multicolumn{2}{|c|}{9.6} & \multicolumn{2}{|c|}{10.5} \\
\hline
\end{tabular}

${ }^{1}$ Means followed by the same uppercase letter in the same column and the same lowercase letter in the same row do not differ at 0.05 probability by Tukey's test

Table 5. Number of ripe ears and 100-grain weight of the two maize cultivars subjected to different methods of weed control ${ }^{1}$

\begin{tabular}{|c|c|c|c|c|c|c|}
\hline \multirow{3}{*}{ Method of weed control } & \multicolumn{3}{|c|}{ Number of mature ears ha $^{-1}$} & \multicolumn{3}{|c|}{ 100-grain weight (g) } \\
\hline & \multicolumn{6}{|c|}{ Hybrid } \\
\hline & AG1051 & BR205 & Mean & AG1051 & BR205 & Mean \\
\hline No hoeing & 20232 & 24022 & $22127 \mathrm{C}$ & 19.8 & 17.3 & 18.6 D \\
\hline Hoeing 20 and 40 after sowing the maize (DASM) & 34000 & 40770 & $37385 \mathrm{~A}$ & 27.8 & 26.4 & $27.1 \mathrm{~A}$ \\
\hline Intercropping with sabiá at the time of sowing the maize & 20058 & 24985 & $22522 \mathrm{C}$ & 23.6 & 19.0 & $21.3 \mathrm{C}$ \\
\hline Hoeing 20 DASM and intercropping with sabiá after hoeing & 31154 & 41862 & $36508 \mathrm{AB}$ & 24.3 & 22.3 & 23.3BC \\
\hline Intercropping with sabiá at the time of sowing the maize and hoeing 40 DASM & 30087 & 35888 & 32988 B & 25.8 & 24.6 & $25.2 \mathrm{AB}$ \\
\hline Mean & $27106 \mathrm{~b}$ & $33506 \mathrm{a}$ & & $24.3 \mathrm{a}$ & $21.9 \mathrm{~b}$ & \\
\hline DMS for hybrids & & 2902.1 & & & 0.89 & \\
\hline DMS for method of weed control & & 4396.6 & & & 2.3 & \\
\hline $\mathrm{CV}_{\text {plot }}(\%)$ & & 12.1 & & & 4.8 & \\
\hline $\mathrm{CV}_{\text {subplot }}(\%)$ & & 11.2 & & & 7.7 & \\
\hline
\end{tabular}

${ }^{1}$ Means followed by the same uppercase letter in the same column and the same lowercase letter in the same row do not differ at 0.05 probability by Tukey's test 
Table 6. Number of grains per ear and grain yield of two maize cultivars using methods of weed control ${ }^{1}$

\begin{tabular}{|c|c|c|c|c|c|c|}
\hline \multirow{3}{*}{ Method of weed control } & \multicolumn{3}{|c|}{ Number of grains per ear } & \multicolumn{3}{|c|}{ Grain yield $\left(\mathrm{kg} \mathrm{ha}^{-1}\right)$} \\
\hline & \multicolumn{6}{|c|}{ Hybrid } \\
\hline & AG 1051 & BR 205 & Mean & AG 1051 & BR 205 & Mean \\
\hline No hoeing & $308 \mathrm{Db}$ & $367 \mathrm{Da}$ & 337 & $1451 \mathrm{Db}$ & $2075 \mathrm{Da}$ & 1763 \\
\hline Hoeing 20 and 40 after sowing the maize (DASM) & $431 \mathrm{Ab}$ & $454 \mathrm{ABa}$ & 442 & $3167 \mathrm{Ab}$ & $5609 \mathrm{Aa}$ & 4388 \\
\hline Intercropping with sabiá at the time of sowing the maize & $331 \mathrm{CDb}$ & $422 \mathrm{Ca}$ & 377 & $1586 \mathrm{Db}$ & $2637 \mathrm{Da}$ & 2111 \\
\hline Hoeing 20 DASM and intercropping with sabiá after hoeing & $401 \mathrm{Bb}$ & $461 \mathrm{Aa}$ & 431 & $2961 \mathrm{Bb}$ & $4919 \mathrm{Ba}$ & 3940 \\
\hline Intercropping with sabiá at the time of sowing the maize and hoeing 40 DASM & $353 \mathrm{Cb}$ & $426 \mathrm{CDa}$ & 390 & $2237 \mathrm{Cb}$ & $3994 \mathrm{Ca}$ & 3115 \\
\hline Mean & 365 & 426 & - & 2280 & 3847 & - \\
\hline DMS for hybrids & & 36.8 & & & 469.1 & \\
\hline DMS for method of weed control & & 19.8 & & & 551.4 & \\
\hline $\mathrm{CV}_{\text {plot }}(\%)$ & & 11.8 & & & 19.5 & \\
\hline $\mathrm{CV}_{\text {subplot }}(\%)$ & & 3.8 & & & 13.9 & \\
\hline
\end{tabular}

${ }^{1}$ Means followed by the same uppercase letter in the same column and the same lowercase letter in the same row do not differ at 0.05 probability by Tukey's test

intercropping with sabiá after hoeing produced the best results (Table 6). For both hybrids, intercropping with sabiá resulted in a larger number of grains per ear compared to lack of hoeing, which suggests a beneficial effect of intercropping on this component of maize production. The remaining treatments resulted in intermediate results. Hybrid BR205 was superior to the other hybrid under all weed-control treatments (Table 6). The best grain yield was obtained with two hoeings, and the worst grain yield was obtained with no hoeing and intercropping with sabiá. The remaining treatments resulted in intermediate yields. Moreover, hybrid BR205 responded better than hybrid AG1051 in terms of grain yield in response to all of the weedcontrol treatments (Table 6).

The presence of weeds reduced most of the characteristics of maize evaluated in this study (Tables 5 and 6 ). The weeds reduced crop yields by competing with the crops for water, nutrients, and light. A reduction in grain yield due to weeds has also been observed in previous studies (Silva et al., 2009).

Intercropping the maize with sabia when sowing the maize resulted in beneficial effects on the maize, as was reflected in the 100-grain weight (Table 5) and the number of grains per ear (Table 6), and the averages obtained with intercropping were higher than those obtained with lack of hoeing. This finding demonstrate that the sabia partially controlled the weeds, which may be due to the results of competition for water, light, nutrients, and space, as well as allelopathy (Ferreira et al., 2010).

The combination of hoeing and intercropping with sabiá provided more benefits to maize compared to simply intercropping with sabiá. This combination was enhanced by two hoeings in terms of the grain yield (Table 6). In six cases, Tukey's test was performed to analyse the maize yield and to evaluate the characteristics related to maize yield (Tables 5 and 6), and hoeing 20 days after sowing the maize (DASM) followed by intercropping with sabiá were found to be superior in five of the six cases compared to the treatment involving intercropping with sabia at the time of sowing the maize and subsequent hoeing 40 DASM. However, the opposite trend was observed in one case (Table 5).

The superiority of hoeing 20 days after sowing the maize (DASM) and intercropping with sabiá after hoeing compared to the combination of hoeing and intercropping examined in this study may be related to the so-called critical period of weed control (CPWC) with respect to most of the evaluated characteristics. The CPWC is the minimum time that a crop should be maintained weed-free in order to prevent unacceptable losses in yield (Zimdahl, 1981). Zimdahl (1981) reviewed 11 similar studies of maize and concluded that the CPWC varies from 14 to 42 days after sowing. This period may explain why hoeing 20 days after sowing the maize (DASM) was generally more advantageous than hoeing 40 DASM. However, because the hoeing was performed 40 DASM, it was still included within the CPWC and thus resulted in beneficial effects on the maize.

The hybrids $(\mathrm{H})$, methods of weed control $(\mathrm{C})$ and the $\mathrm{H} \times$ $\mathrm{C}$ interaction affected the fresh and dry matters of weed shoots (Table 4) and grain yield (Table 6). In the two hybrids, the lowest growth (dry matter) of weeds occurred both with hoeing and the integrated weed management systems. However, in the two hybrids, the higher grain yields were obtained with two hoeings.

\section{Conclusions}

1. Lesser weed growth in the plots of the two hybrids was observed with the treatments that involved hoeing.

2. The highest yields for maize were obtained with two hoeings.

3. The combinations of hoeing and intercropping provided higher grain yield compared to only intercropping with sabiá. Grain yield with hoeing 20 days after sowing the maize (DASM) and intercropping with sabiá was higher compared to intercropping with sabiá and hoeing 40 DASM.

\section{Literature Cited}

Borgy, B.; Gaba, S.; Petit, S.; Reboud, X. Non-random distribution of weed species abundance in arable fields. Weed Research, v.52, p.383389, 2012. http://dx.doi.org/10.1111/j.1365-3180.2012.00920.x

Buhler, D. D. Weed population responses to weed control practices. I. Seed bank, weed populations, and crop yields. Weed Science, v.47, p.416-422, 1999.

Chikoye, D.; Manyong, V. M.; Carsky, R. J.; Ekeleme, F.; Gbehounou, G.; Ahanchede, A. Response of speargrass (Imperata cylindrica) to cover crops integrated with handweeding and chemical control in maize and cassava. Crop Protection, v.21, p. 145-156, 2002. http:// dx.doi.org/10.1016/S0261-2194(01)00078-3

Dias, L. A. S.; Barros, W. S. Biometria experimental. Viçosa: UFV, 2009. 408p.

Ekpo, T. U. U.; Udosen, U. U.; Udom, G. N. Performance of maize as influenced by different weed management options in the rainforest zone of Nigeria. Nigerian Journal of Agriculture, Food and Environment, v.6, p.1-5, 2010. 
EMBRAPA - Empresa Brasileira de Pesquisa Agropecuária. Centro Nacional de Pesquisa do Solo. Sistema brasileiro de classificação de solos. Brasília: Serviço de Produção de Informação, 2006. 306p.

Ferreira, E. G. B. S.; Matos, V. P.; Sena, L. H. M.; Sales, A .G. F.A. Efeito alelopático do extrato aquoso de sabiá na germinação de sementes de fava. Revista Ciência Agronômica, v.41, p.463-467, 2010. http:// dx.doi.org/10.1590/S1806-66902010000300020

Harker, K. N.; O'Donovan, J. T. Recent weed control, weed management, and integrated weed management. Weed Technology, v.27, p.1-11, 2013. http://dx.doi.org/10.1614/WT-D-12-00109.1

Oliveira, A. M.; Silva, P. S. L.; Albuquerque, C. M. S. B.; Cardoso, M. J.; Oliveira, O. F. Weed control in corn via intercropping with gliricidia sown by broadcasting. Planta Daninha, v.29, p.535-543, 2011. http:// dx.doi.org/10.1590/S0100-83582011000300007

Olorunmaiye, P. M. Economic viability of integrated weed management in maize/cassava intercrop in Guinea savanna ecology of Nigeria. Agriculture \& Biology Journal of North America, v.2, p.522-525, 2011. http://dx.doi.org/10.5251/abjna.2011.2.3.522.528

Ribeiro Júnior, J. I. Análises estatísticas no SAEG. Viçosa: Universidade Federal de Viçosa, 2001. 301p.

Ronald, M.; Peter, J.; Charles, K.; Tibugari, H. Integrated weed management in Zimbabwe's smallholder sector, where are we?: a review. Modern Applied Science, v.5, p.111-117, 2011. http://dx.doi. org/10.5539/mas.v5n5p111
Sanyal, D.; Bhowmik, C.; Anderson, R. L.; Shrestha, A. Revisiting the perspective and progress of integrated weed management. Weed Science, v.56, p.161-167, 2008. http://dx.doi.org/10.1614/WS-07108.1

Silva, F. C. (ed.). Manual de análises químicas de solos, plantas e fertilizantes. 2.ed. Brasília: Embrapa Informação Tecnológica, 2009. 627p.

Silva, P. S. L.; Damasceno, A. P. A. B.; Silva, K. M. B.; Oliveira, O. F; Queiroga, R.C.F. Growth and yield of corn grain and green ear in competition with weeds. Planta Daninha, v.27, p.947-955, 2009. http://dx.doi.org/10.1590/S0100-83582009000500008

Yeganehpoor, F.; Salmasi, S.Z.; Solymani, A.; Valizadeh, M.; Samadiyan, F. Effects of hoeing and not hoeing of weed and using of companion plants on some agronomic traits of corn Sc 504 . International Journal of Agronomy and Plant Production, v.4, p.1033-1039, 2013.

Zimdahl, R. L. The concept and application of the weed-free period. In: Altieri, M.A.; Liebman, M. (coord.). Weed management in agroecosystems: Ecological approaches. New York: CRC Press, 1981. p.145-154.

Zystro, J. P.; Leon, N.; Tracy, W. F. Analysis of traits related to weed competitiveness in sweet corn (Zea mays L.). Sustainability, v.4, p.543-560, 2012. http://dx.doi.org/10.3390/su4040543 